\title{
Analysis of Influenced Factors on Consumer Behaviour: The Demand of Chicken Egg's in TebingTinggi City
}

\author{
S H Putri, A H Daulay, Hamdan, E Mirwandhono, TH Wahyuni \\ Animal Production Program Study, Faculty of Agriculture, University of Sumatera Utara, Medan 20155, \\ Indonesia \\ E-mail: siti.hanifahputri11@gmail.com
}

\begin{abstract}
The purpose of this study were to identify factors that affect the demand for chicken eggs and to find out the correlation of factors that affect consumer behavior in purchasing chicken eggs in Tebing Tinggi City. The research used primary data obtained from questionnaires or interviews. The research method was multiple linear regression methods, spearman rank correlation and contingency correlation.

The results showed that the price of chicken eggs and the income had real effect to the demand for chicken eggs in the area of research. The result of spearman rank correlation and the contingency correlation showed that there was a real correlation between the income with a consumer behavior in purchasing chicken eggs, while the age, employment, and number of consumer dependents, did not show real correlation with consumer behavior in purchasing chicken eggs.
\end{abstract}

\section{Introduction}

Broiler chicken eggs are one of the popular sources of animal protein in the public. Broiler chicken eggs are relatively cheap and easy to obtain. Due to these factors, almost all people can consume broiler chicken eggs to meet the expected nutritional needs (animal protein). (Lestari, 2009) [1]. The average consumption of broiler chicken eggs per capita per year in Indonesia has increased by 97,398 eggs in 2015 and 99,796 eggs in 2016 (Directorate General of PKH, 2016) [2].

Based on data from the Central Statistics Agency (BPS) of Tebing Tinggi City, in 2016, Tebing Tinggi had a population of 158,902 people. Chicken egg production in the year of 2011 to 2015 sequentially was 343,719 eggs, 360,904 eggs, 362,708 eggs, 371,775 eggs, and 360,105 eggs. The percentage of the population of Tebing Tinggi city with annual production of broiler chicken eggs is $11.3 \%$ [3].

\section{Materials and Methods}

2.1 Time and Location of Research

The research was conducted in Tebing Tinggi City and began in July 2018.

\subsection{Sampling Methods}

The sample determining method is the trace (Accidental) method, which is done by taking random respondents who happen to buy chicken eggs in several traditional markets in Tebing Tinggi City. Those markets are Gambir market, Inpres market, and Sakti market. The requirements for the sample are as follows: the sample is a consumer who shops for chicken eggs. Determination of the sample in this research are all consumers who bought chicken eggs found in traditional markets in Tebing Tinggi City. According to the Bailey theory, the minimum number of samples for researches using statistical analytics is 30 samples (Hasan, 2002) [4].

\subsection{Method of collecting}

Data in this research is collected using primary and secondary data. Primary data is obtained by direct interview with sample consumers using customized questionnaire. Secondary data is obtained from various literatures, books or journals, related institutions, and also previous researches related to consumers behaviour towards demand for broiler chicken eggs. 


\subsection{Data Analysis Method}

Collected data is then analyzed using the hypothesis that is going to be tested:

Annotation:

$$
\mathrm{Y}=\mathrm{a}+\mathrm{b}_{1} \mathrm{X}_{1}+\mathrm{b}_{2} \mathrm{X}_{2}+\mathrm{b}_{3} \mathrm{X}_{3}+\mathrm{b}_{4} \mathrm{X}_{4}+\mu
$$

$\mathrm{Y}=$ Amount of demand of broiler chicken eggs (eggss/month)

a $\quad=$ Constant

$\mathrm{b} \quad=$ Regression coefficient

$\mathrm{X}_{1} \quad=$ Price of broiler chicken eggs (Rp/month)

$\mathrm{X}_{2} \quad=$ Average income $(\mathrm{Rp} / \mathrm{month})$

$\mathrm{X}_{3} \quad=$ Number of dependants (People)

$\mathrm{X}_{4} \quad=$ Price of tempeh $(\mathrm{Rp} / \mathrm{Bar})$

$\mu \quad=$ Disturbance error

2.5 Goodness of Fit Test

Determination Coefficient $\left(\mathrm{R}^{2}\right)$

This coefficient is a measurement in which independent variable can influence dependent variable in a relation. This coefficient indicates percentage of free variation (Supriana, 2013) [5].

\subsection{Test (F-test)}

F-test is simultaneous test on independent variable effect towards control variable. F-test indicates whether all independent variables used in the model have simultaneous effect towards dependent variables.

\subsection{Partial Test (t-test)}

t-test is statistical test to see whether each independent variable has effect on control variables. The significance level $(\alpha)$ used is $5 \%$.

\subsection{Classical Assumption Test}

This test aims to test whether the model that is going to be used is free from any classical assumption deviation. OLS (Ordinary Least Square) method is used for this purpose. Therefore, several assumptions must be fulfilled such as:

\subsection{Multicollinearity Test}

Multicollinearity test aims to test whether regression model finds correlation between independent variables. Good regression model should not have correlation between independent variables. If there is correlation between independent variables, then the variables are not orthogonal. (Ghozali, 2005) [7].

\subsection{Heteroskedasticity Test}

Heteroskedasticity test aims to test whether in regression model there is varian inequality from one observation residual to the other. Residual varian that constant from one observation to the other is homoscedasticity, otherwise it is heteroskedasticity.

\subsection{Assumption of Normality Test}

Normality test is used to test assumption on data normality. Good regression model residual which has normal distribution. Normality test aims to test whether in regression model, disturbance variable or residual has normal distribution (Sujarweni, 2015).

\subsection{Spearman's Rank Correlation Coefficient Test}

Statistical data analysis method used in this research is Spearman's Rank correlation method. Jonathan and Elly (2010) stated that Spearman's Rank correlation is used to identify correlation or effect between two variables in ordinal scale, they are independent and dependent variable. The formula of correlation analysis is as follows (Sugiyono, 2013) [9]. 


$$
\begin{gathered}
\mathrm{rs}=1 \frac{6 \sum \mathrm{di}^{2}}{\mathrm{~N}\left(\mathrm{n}_{z}-1\right)} \\
\text { thitung }=r s \sqrt{\frac{n-2}{1-r s^{2}}}
\end{gathered}
$$

Annotation:

$$
\begin{array}{ll}
\mathrm{Rs} & =\text { Spearman's rank correlation value } \\
\mathrm{di} & =\text { Difference between ranks } \\
\mathrm{n} & =\text { Amount of sample } \\
\Sigma & =\text { Summation notation }
\end{array}
$$

2.13 Contingency Correlation Coefficient Test

Contingency coefficient is a method used to measure relation (assosiation or correlation) between 2 variables in nominal data type (categorical) (Sugiyono, 2003) [10].

\section{Results and Discussion}

Factors Affecting the Demand on Broiler Chicken Egg

3.1 Classical Assumption Test

Table 11. Multicollinearity test result of demand on broiler chicken eggs using colinearity statistic

\begin{tabular}{llll}
\hline No. & Independent Variables & Tolerance & VIF \\
\hline 1 & Price of Broiler Chicken Egg & 0,831 & 1,203 \\
2 & Revenue & 0,836 & 1,196 \\
3 & Number of Dependents & 0,995 & 1,047 \\
4 & Price of Tempeh & 0,984 & 1,017 \\
\hline
\end{tabular}

Source: processed Primary Data

Table 11 shows Tolerance's value from all independent variables are larger than 0,1 and VIF's value from all independent variables are smaller than 10. From this result, it can be concluded that there is no multicollinearity violation in the model being used.

3.2 Heteroskedasticity test is performed using Glejser test. Test result can be seen in Table 12 .

Table 12. Test result of heteroskedasticity assumption on broiler chicken eggs's model

\begin{tabular}{lll}
\hline No. & Independent Variables & Sig \\
\hline 1 & Price of Broiler Chicken Egg & 0,522 \\
2 & Revenue & 0,460 \\
3 & Number of Dependents & 0,298 \\
4 & Price of Tempeh & 0,148 \\
\hline
\end{tabular}

Source: processed Primary Data

Table 12 shows that there is no violation on heteroskedasticity assumption. Using classical assumption that has been performed, it can be concluded that the model being used falls in good model category because it fulfills predetermined assumptions.

3.3 Goodness of Fit Test and Hypothetical Test

Factors which affect demand on broiler chicken eggs can be seen in Table 13.

Table 13. Analysis on factors affecting the demand on broiler chicken eggs in Tebing Tinggi City

\begin{tabular}{lllll}
\hline Independent Variables & Regression Coefficient & $t_{\text {Hitung }}$ & Sig & Exp \\
\hline Constant & 345,048 & 11,108 & 0,000 & \\
\hline
\end{tabular}




\begin{tabular}{lllll}
\hline Price of Broiler Chicken Egg & $-0,220$ & $-10,285$ & 0,000 & $\mathrm{~N}$ \\
Revenue & 0,0000030 & 2,135 & 0,035 & $\mathrm{~N}$ \\
Number of Dependents & 1,335 & 1,220 & 0,226 & tn \\
Price of Tempeh & 0,001 & 0,667 & 0,506 & $\mathrm{rn}$ \\
\hline $\mathrm{R}^{2} \quad=0,631$ & & & & \\
Fhit $=40,610$ & & & \\
Sig. $\quad=0,000$ & & & \\
Annotation: & & & \\
$\mathrm{n} \quad=$ have real impact & & & \\
$\mathrm{tn} \quad=$ doesn't have real impact & & & \\
\hline Source: processed Primary Data & & &
\end{tabular}

Source: processed Primary Data

From Table 13, it can be defined the formula for multiple linear regression as follows:

$$
\mathrm{Y}=345,048-0,220 \mathrm{X} 1+0,000003061 \mathrm{X} 2+1,335 \mathrm{X} 3+0,001 \mathrm{X} 4
$$

3.4 Determinant Coefficient $\left(\mathrm{R}^{2}\right)$

Analysis result indicates that determinant coefficient or $\mathrm{R}^{2}$ in the amount of 0,631 which means $63,1 \%$ variables variation of demand on chicken broiler eggs can be explained by variables variation of price of broiler chicken eggs, income, number of dependants, and price of tempeh, and the remaining $36,9 \%$ can be explained by other variables that are not included in the model.

\subsection{Simultaneous Test (F-Test)}

Analysis result indicates that Table 13 shows the value of $F_{\text {hitung }}$ is 40,61 . This means that variables of price of broiler chicken eggs, income, number of dependants, and price of tempeh is simultaneously and distinctively affecting demand on broiler chicken eggs.

\subsection{Partial Test (t-test)}

\section{a. Price of broiler chicken eggs}

Analysis result shows regression coefficient of price of broiler chicken eggs in the amount of $-0,220$ which indicates that price increase in the amount of Rp100/eggs is going to decrease demand of broiler chicken eggs as big as 22 eggs/month. Based on partial test, analysis result on demand of broiler chicken eggs is $t_{\text {hitung }}$ in the amount of $-10,285$ therefore it can be concluded that the price of broiler chicken eggs is distinctively affects demand on broiler chicken eggs in the research area.

Research shows the price of broiler chicken eggs in research area tends to fluctuate between Rp1.200 - Rp1.500 per egg. Broiler chicken eggs at price level Rp1.200 per egg will have demand from a single household up to 120 eggs per month. But at price level Rp1.500 per egg, demand on broiler chicken egg only goes up to 45 eggs per month.

\section{b. Income}

Analysis result shows regression coefficient in the amount of 0,000003061 which indicates income increase as big as Rp1.000.000/month is going to increase demand on broiler chicken eggs as big as 3,06 eggs/month. Based on partial test, analysis result on demand of broiler chicken eggs is $t_{\text {hitung }}$ in the amount of $-2,135$ with significance level of 0,05 . Therefore it can be concluded that income distinctively affects demand on broiler chicken eggs in the research area.

Research shows that consumers' income is varies starting from Rp500.000 - Rp7.500.000 per month. Consumer with income of Rp500.000 per month only has demand on broiler chicken eggs only 25 eggs per month. Meanwhile, consumers with income up to Rp7.500.000 has demand on broiler chicken eggs up to 90 eggs per month.

Based on the result, it shows that consumer's income varies from Rp. 500,000 - Rp. 7,500,000 per month. Consumers with income rate of Rp. 500,000,- per month only demand 25 items of broiler 
chicken eggs per month. While consumers with up to Rp. 7,500,000 income per month demand for up to 90 items of broiler chicken eggs per month.

c. Number of Consumer Dependent

Based on the analysis, the research obtained a regression coefficient for the number of consumer dependents of 1.335 which means an increase in the number of customer dependents by 1 person, will increase the demand for chicken eggs by 1.3 items / month. Based on the statistical partial test, the demand for chicken eggs obtained $t_{\text {hitung }}$ of 1.220 with a significance value of 0.226 at the level of $\alpha=$ 0.05 . Therefore, it can be concluded that the number of consumer dependents has no significant effect on the demand for chicken eggs in the research area.

\section{d. Tempe Price}

The research obtained a regression coefficient for tempeh price of 0.001 which means that an increase in the price of tempeh of Rp 1,000 / block will increase the demand for chicken eggs by 1 item/month. Based on the statistical partial test, the demand for chicken eggs obtained $t_{\text {hitung }}$ of 0.667 with a significance value of 0.506 . Therefore, it can be concluded that the price of tempeh had no significant effect on the demand for eggs in the research area.

Correlation Between Consumer Characteristics and Behavior in Buying Broiler Chichken Eggs. Following is the result of Consumer Behavior Expected Score in buying broiler chicken egg

Table 17. Consumer Behavior Expected Score

\begin{tabular}{llll}
\hline Parameter & Expected Score & Consumer Behavior Score & Percentage $(\%)$ \\
\hline 1 & $1-5$ & 3.83 & 29.83 \\
2 & $1-5$ & 4.32 & 33.64 \\
3 & $1-5$ & 2.91 & 22.66 \\
4 & $1-5$ & 1.78 & 13.86 \\
\hline Total & $4-20$ & 12.84 & 100.00 \\
\hline
\end{tabular}

Source: Processed Primary Data

From Table 17, it can be seen that parameter 2 is the parameter with the largest percentage of the total score of consumer behavior. Parameter 2 obtained an average score of consumer behavior of 4.32 or $33.64 \%$. Parameter 4 is the parameter with the smallest percentage of the total score of consumer behavior. Parameter 4 scores 1.78 or $13.86 \%$. The consumer behavior high or low scores can be seen from the expected score of Parameter 4, which ranges from 4-20. If the score is 4-9, then the consumer behavior is low. If the score is $10-15$, then the consumer behavior is moderate, and if the score is $16-20$, then the consumer behavior is high.

3.7 The consumer frequency based on the consumen behavior can be seen from the following Table.

Table 18. Consumer Frequency Based on The Consumer Behavior

\begin{tabular}{lllll}
\hline \multirow{2}{*}{ Explanation } & \multicolumn{3}{c}{ Consumen Behavior Score } & \multirow{2}{*}{ Total } \\
\cline { 2 - 4 } & Low & Medium & High & 100 \\
\hline Frequency & 2 & 88 & 10 & 100 \\
Persentage (\%) & 2 & 88 & 10 & \\
\hline
\end{tabular}

Source: Processed Primary Data

From Table 18, it can be seen that majority of consumer's behavior in buying broiler chicken eggs is in the category of medium, 88 persons or $88 \%$.

3.8 Correlation Between Consumer Age and Behavior in Buying Broiler Chicken Eggs

Spearman rank correlation analysis was used to determine correlation between Consumer age and behavior in buying broiler chicken eggs. Based on the results of spearman rank correlation analysis, a 
significance value of 0.174 is obtained, which means that there is no correlation between consumer's age and behavior in buying chicken eggs on the research locus.

3.9 Correlation Between the Number of Consumer Dependents and Consumer Behavior in Buying Broiler Chicken Eggs

Spearman rank correlation analysis was used to determine correlation between the number of consumer dependents and consumer behavior in buying broiler chicken eggs. Based on the results, a significance value of 0.468 is obtained, which means that there is no correlation between the number of consumer dependents and behavior in buying chicken eggs on the research locus.

3.10 Correlation Between Consumer Job and Behavior in Buying Broiler Chicken Eggs

Contingency correlation analysis was used to determine correlation of consumer job and behavior in buying broiler chicken eggs. Based on the results, a significance value of 0.727 is obtained, which means that there is no correlation between consumer job and behavior in buying broiler chicken eggs on the research locus.

3.11 Correlation Between Consumer Income and Behavior in Buying Broiler Chicken Eggs Spearman rank correlation analysis is used to determine the correlation between the income and comsumers behavior in buying race chicken eggs. The result shows significant value of 0,000 which means that there is a correlation between income and consumers behavior in buying broiler chicken eggs in the research locus.

\section{Conclusion}

The price of broiler chicken eggs and consumer income are significantly affected the demand of broiler chicken eggs, while the number of consumer dependents and prices of tempeh has no significant effect on the demand of broiler chicken eggs on the research locus. There is a significant correlation between income and consumer behavior in buying broiler chicken eggs, while age and number of consumer dependents and consumer job don't have a real correlation with consumer behavior in buying broiler chicken eggs.

\section{References}

[1] Lestari, P, I. 2009. Kajian Supply Chain Management: Analisis Relationship Marketing antara Peternakan Pamulihan Farm dengan Pemasok dan Pelanggannya. Institut Pertanian Bogor.Bogor.

[2] Direktorat Jenderal Peternakan dan Kesehatan Hewan (Ditjen PKH). 2016. Statistik Peternakan dan Kesehatan Hewan.Kementerian Pertanian RI- http://ditjennak.pertanian.go.id. Indonesia

[3] Badan Pusat Statistik Kota Tebing Tinggi. 2017. Tebing Tinggi Dalam Angka 2017

[4] Hasan, M, I. 2002. Metodologi penelitian dan Aplikasinya.Ghalia Indonesia. Jakarta.

[5] Supriana, T. 2013. Pengantar ekonometrika. USU PRESS: Medan.

[6] Gujarati, D. 2006. Ekonometrika Dasar. Terjemahan.Erlangga. Jakarta

[7] Ghozali, Imam. 2005. Aplikasi Analisis Multivariate dengan Program SPSS. Edisi Ketiga. Semarang. Universitas Diponegoro

[8] Sujarweni, V. W. 2015. SPSS Untuk Penelitian. Yogyakarta (ID): Pustaka Baru PressSukirno, S. 2003. Pengantar Teori Mikroekonomi (Edisi Ketiga). Jakarta: Grafindo.

[9] Sugiyono. 2013. Metodelogi Penelitian Kuantitatif, Kualitatif dan R\&D. Bandung: Alfabeta

[10] Sugiyono.2003. Statistik Nonparametrik untuk Penelitian.Bandung: CV Alfabeta 